\title{
Demokrasinin Doğulu Kökenlerine Dair Bir İnceleme
}

\section{A Study on the Eastern Origins of Democracy}

\author{
Dr. Ramazan LEVENT (iD)
}

\begin{abstract}
$\ddot{\mathbf{O z}}$
Demokrasi tarihi ile ilgili yapılan çalışmalarda batı tarihine endeksli bir çabanın söz konusu olduğu görülmektedir. Bu çalışmada doğu tarihindeki bazı demokrasi örnekleri ele alınmaktadır. Antik İsrail Devletinin kuruluşu sürecinde krallık yapan Davut ve Süleyman peygamberlerin yönetimleri bu yaklaşımla incelenmiştir. Kaynak olarak en başta Kitab-1 Mukaddes verilerine yer verilmiştir. İslami kaynaklarla da konu desteklenmiştir. Diğer bir örnek olarak Süleyman Peygamber zamanında yaşayan Sebe Melikesinin yönetim şekli değerlendirilmiştir. Tevrat’ta Sebe melikesinin yönetiminin içeriği ile ilgili bir veri bulunmadığı için bu kitap kaynak olarak kullanılamamıştır. Melikenin yönetim modeli için Kur'an'ın ifadeleri değerlendirilmiştir. Hem Davud-Süleyman peygamberlerin yönetimleri hem Sebe Melikesinin yönetimleri incelenerek bazı çıkarımlarda bulunulmuştur. Demokrasinin doğu toplumlarında MÖ XII. yy’a kadar dayanan bir tarihinin olduğu görülmüştür.
\end{abstract}

Anahtar Kelimeler: Kitab-1 Mukaddes, Kur'an, Belkıs, Süleyman Peygamber, mesh etmek

Makale Türü: Derleme

\begin{abstract}
In the studies on the history of democracy, it is seen that there is an effort indexed to the western history. In this study some examples of democracy in eastern history are discussed. The governance of the prophets of David and Solomon, who made the kingdom in the foundation of the ancient state of Israel, were examined with this approach. In the first place, the Torah and Bible data are given as the source. The subject was also supported by Islamic sources. As another example, the Sebe queen's administration method, who lived in the time of the Prophet Solomon, was evaluated. This book was not used as a reference since there is no data on the content of the Sebe administration in the Torah. Qur'an's statements were evaluated for the queen's management model. Both the administration of the prophets of David / Suleiman and the queen of Sebe have been examined and some inferences have been made. In Eastern societies. It was seen that democracy had a history dating back to the X. century BC.
\end{abstract}

Keywords: Torah, Qur'an, Belkis, Prophet Solomon, anoint

Paper Type: Review

${ }^{1}$ Malatya Eğitim ve Araştırma Hastanesi, rlevent44@hotmail.com.

Atıf için (to cite): Levent, R. (2020). Demokrasinin doğulu kökenlerine dair bir inceleme. Afyon Kocatepe Üniversitesi Sosyal Bilimler Dergisi, 22(3), 815-826. 


\section{Giriş}

Demokrasinin tarihi ve başlangıcı ile ilgili yapılan çalışmalarda kavramın etimolojik olarak Eski Yunan'a ait olduğu belirtilerek ilk demokratik tecrübelerin en eski tarihinin Antik Yunan'da aranması gerektiği belirtilir. Demokrasi üzerinde yapılan bu değerlendirme demokrasinin Doğu toplumlarına ait kökenlerinin göz ardı edilmesine neden olmuştur. Bu makalede mevcut literatürde demokrasi olarak nitelendirilen yönetim şeklinin iptidai tecrübelerinin Eski Yunan'dan da önce Doğu toplumlarındaki bazı örnekleri üzerinde durulmaktadir.

Konunun anlaşılmasında bütünlük sağlamak amacıyla öncelikle Eski Yunan'daki demokrasinin içeriğinden bahsedilmiş; daha sonra İsrail devletinin kuruluş sürecinde Davut ve Süleyman peygamberlerin iktidara geliş süreçleri incelenmiş ve Sebe Melikesi Belkıs'ın iktidarının içeriği ele alınmıştır. İsrail devletinin kuruluşu ile ilgili Kitab-1 Mukaddeste yer alan bilgiler en eski yazılı veriler olarak işlev görmektedir. İçeriği tahrif edilmiş olmasından dolayı, gerçeklik derecesi hakkında kuşkular bulunan (örnek için bkz. Mendenhall, 2016, s. 143) bu kaynakta yer alan bilgilerin bașta İslam'ın sahih metinleri olmak üzere diğer kaynaklarla desteklenmesi gerekmektedir. Bu çalışmada Kitab-1 Mukaddeste yer alan bilgiler ipucu olarak değerlendirilmiş ve İslami kaynaklar da göz önünde bulundurularak konu hakkında bazı sonuçlara varılmaya çalışılmıştır.

İnsanlık tarihinin en eski yazılı kaynaklarından olan kutsal dini metinlerde anlatılanlar konu hakkında önemli bilgiler içermektedir. Peygamberler tarihi üzerine yazılan metinler demokratik uygulamaların Eski Yunan'dan önce Davut ve Süleyman peygamberler döneminde tecrübe edildiğini göstermektedir. Ayrıca İran, Hint, Çin ve diğer doğu toplumları ile ilgili yapılacak çalışmalardan sonra ilk demokratik uygulamaların hangi medeniyette görüldüğüne karar verilmelidir. Konu üzerinde neredeyse hiç çalışma yapılmadığından dolayı kaynak eksikliği kendini hissettirse de var olan metinlerde yer alan ipuçları bazı sonuçlara ulaşmak için önemli veriler olarak işlev görmektedirler. En önemli aydınlatıcı bilgilerin İsrailoğulları/Yahudi tarihinde yer aldığı bilinmelidir.

\section{Yöntem}

Bu çalışma bir araştırma makalesidir. Çalışmada doğu toplumlarında Antik Yunan'dan daha önce demokratik tecrübelerin iptidai örneklerinin yaşanıp yaşanmadığı incelenmektedir. İnceleme esnasında en eski yazılı kaynaklardan olan Kitab-1 mukaddes verileri, Kuran ve diğer bazı İslami kaynaklar kullanılmıştır. Eski Yunan demokrasisinin özellikleri literatür çalışması ile kısaca özetlenmiş ve bu özelliklerin Antik İsrail kralları olan Davut ve Süleyman peygamberlerin iktidarlarında ne derecede bulunduğu incelenmiştir. Ayrıca Kuran'da kıssası anlatılan ve Süleyman Peygamberle çağdaş olan Sebe Melikesi Belkıs'ın iktidarında hangi demokratik niteliklerin bulunduğu, konuyu işleyen İslami kaynaklar incelenerek ortaya konulmaya çalışılmıştır. Çıkan sonuçta iptidai özellikler taşısa da bazı demokratik uygulamaların Antik Yunan'dan önce Antik İsrail ve bazı orta doğu yönetimlerinde tecrübe edildiği sonucuna ulaşılmıştır.

\section{Antik Yunan'da Demokrasi}

Eski Yunan'da bugün için ilk ve en önemli demokratik uygulamalar olarak değerlendirilen çalışmalar, M.Ö. 507'de iktidarı darbe ile elde etmiş bir aristokrat olan Kleisthenes döneminden başlatılmaktadır. Kleisthenes iktidar olduğunda 'Genos' denilen ve kan bağına göre oluşan örgütlenmelerin yerine bölgesel nitelikli 'Deme' ${ }^{2}$ örgütlerini kurdu. Atina 10 Deme'ye ayrıldı ve her Deme'den 50 kişi olacak şekilde 'Beşyüzler Meclisi' kuruldu (Şenel,

\footnotetext{
${ }^{2}$ Demokrasi kavramının da kökeninde bu ifade bulunmaktadır.
} 
1995, s. 118-9). Bu meclis Atina'daki kabileleri temsilen kura ile belirlenen beş yüz kişiden oluşmaktaydı. Beşyüzler meclisi iktidar erki için bir danışma konseyi niteliğinde idi ve üyeleri Kleisthenes tarafından atanmıştı (Akgün, 2011, s. 168). ${ }^{3}$ Demokrasinin ilk nüveleri olarak değerlendirilen uygulamaların görüldüğü en önemli merkez olan Atina şehir devletinde en önemli demokratik kurum Halk Meclisiydi (Eklesia). Kadınlar, yabancılar ve kölelerin dışında kalan ve 20 yaş üstü, eli silah tutan erkeklerin katıldığı mecliste çeşitli konular görüşülerek basit çoğunluk yöntemi ile karara bağlanmaktaydı. Farklı sayılarda olanları olmakla birlikte, 320.000 nüfuslu bir poliste 20.000 civarında kişi Halk Meclisine katılma şartlarını sağlamaktaydı $1{ }^{4}$ Halk Meclisi genellikle 5.000-6.000 civarında kişi ile toplanmaktaydı (Çınar, 2016. s. 207). Bu bilgiler çerçevesinde aktif siyasal çalışmalara katılanların oranı nüfusun yaklaşık $1 / 50$ 'si civarındaydı. Siyasal eylemlere katılma yeterliliğine sahip olanlar (Politai) da kendi aralarında çeşitli sınıflara ayrılmışlardı. Politai, Eupatridler (İyi doğmuşlar: Yönetimi ellerinde tutan ve başkalarını bundan mahrum bırakanlar), Demiurgoi (Ticaret ve sanatla zenginleşen kentli orta sınıf), Georgoi (Küçük toprak sahibi köylüler) ve Thetes'ler (arazisi ve belli bir işi olmayan kentli emekçiler) şeklinde kısımlardan meydana gelmekteydiler (tr.wikipedia.org, Atina Demokrasisi maddesi, -Er Tr: 8.5.2020).

Halk meclisinin ilk ortaya çıkma gerekçesi soylu sınıfın içinde yönetimi üstlenenlerin yasaları ve sosyal hayatı düzenleyen kuralları adet ve geleneklere göre yorumlamasıydı. Yasalar sözlü olmakla birlikte tanrı buyruğu olarak kabul edilmekte ve soylu sınıfın yönetici tabakası tarafından uygulanmaktaydı. Bu durum yasaların uygulanmasında bazı suiistimallerin meydana gelmesine neden oluyordu. Alt kademe soylularının aleyhindeki bu durum tepkilere neden oluyordu. Yukarıda bahsedilen Halk Meclisi bu soruna bir çözüm olarak ortaya çıktı. Halk Meclisinde toplanan alt düzeyde soylular ve özgürler sözü edilen yöntemlerle yasaların yazılı hale gelmesini sağladılar. Bu şekilde 'halk' hangi suça hangi cezanın verileceğini öğrenmiş olmaktaydı. Yasaların yazıya geçirilmesinin en önemli sonuçlarından biri polisteki bütün özgürlerin yasa önündeki eşitliğinin sağlanmış olmasıydı. Yeni durumun tehlikesi aristokrat sınıf içinde iktidarı üstlenecek olanın 'tiranlaşma'sıydı. Tiranlaşma iktidarı zorla ele geçiren aristokratın diktatör gibi davranması; diğer bir ifadeyle ya yasalara göre hareket etmemesi veya yasaları eskisi gibi keyfince uygulamasıydı. Yönetimi üstlenen aristokratın halk meclisine yılda bir kez 'Çanak-Çömlek Mahkemesi' olarak çalışma yetkisi vermesi, tiranlaşmaya bir çözüm olarak ortaya çıktı. Çanak Çömlek Mahkemesi toplandı̆̆ında tiran olabileceğinden kuşkulandıkları aristokratların isimlerini çanak çömlek parçalarına yazıyorlardı. Yapılan sayımda ismi 6.000 'den fazla kişi tarafından yazılanlar 10 yıllığına kent dışına sürülmekteydi (Tekin, 2008, s. 73-80).

Antik Yunan'da yarg1 görevini 30 yaş üstü özgürler arasından kurayla belirlenen 6000 kişi yürütmekteydi. ${ }^{5} \mathrm{Bu}$ gurup içinden belirlenen 501 kişi mahkeme heyetini oluşturmuştur. Belirlenen 501 kişi davalarda tarafları dinleyerek suç ve cezalar hakkında karar vermiştir. Mahkemelerin önemli işlevlerinden biri de yöneticilik yapan memurların toplanan vergilerden yaptıkları harcamaları denetlemekti (Çınar, 2016, s. 207).

Eski Yunan'da iptidai bir şekilde uygulanan ve bugün için demokrasinin ilk örnekleri olarak ileri sürülen özelliklere bakıldığında çeşitli sonuçlara ulaşılabilir. Siyaset felsefesinin en önemli konularından olan 'kim yönetecek?' sorusunun cevabı demokratikliğin en önemli mihenklerinden biridir. Bu soru üzerinden Kadim Yunan demokrasisine bakıldığında siyasal iktidarı elde tutan en üst yöneticilerin siyasal haklara sahip vatandaşlar tarafindan belirlendiğini gösteren bir uygulama örneği bulunmamaktadır. En çok iktidarı demokrasi dışı yöntemlerle üstlenen iktidar sahiplerinin, aristokrat yanlısı veya halk yanlısı olup olmadığı söz konusu

\footnotetext{
${ }^{3}$ https://www.academia.edu, (Er. Tr: 7.5.2020) Akgün, E. (2011). “Antik Yunan'da Yurttaşların Özgürlüklerinin Temeli Olarak Demokrasi"

${ }^{4}$ https://www.academia.edu/4023971/Antik_Yunan_Demokrasisi_Modern_Demokrasi_Kar\%C5\%9F\%C4\%B1la\%C5\%9Ft\%C4\% B1rmas\%C4\%B1_Comparison_of_Ancient_Greek_Democracy_and_Modern_Democracy_(Er. Tr: 5.5.2020)

${ }^{5}$ www.academia.edu, (Er Tr: 8.5.2020); Hüner, M. F. “Antik Yunan Demokrasisi- Modern Demokrasi Karşılaştırması”, s. 7
} 
olmuştur. Çanak Çömlek Mahkemesi örneğinde görüldüğü gibi iktidarı elde etmesi muhtemel olanlardan Tiranlaşma eğilimi taşıdığı düşünülenlerin iktidarının engellenmesi; Halk Meclisinin kimin iktidar olacağını değil kimin iktidar olmayacağını belirleme yetkisi olduğunu göstermektedir.

Demokrasinin diğer bir mihengi toplumun yönetilmesinin kuralları olan yasalarda toplumun belirleyicilik düzeyidir. Eski Yunan'da Halk Meclisinin yasa yapıcı olarak işlev gördüğünü gösteren açık bir uygulama örneğine rastlanmamaktadır. Halk Meclisinin yasalar üzerindeki etkisinin yasaların yazılı hale getirilerek sübjektif olarak uygulanmasının ve yargılananın sınıfsal niteliğine göre yorumlanmasının önüne geçmektir. Halk meclisinin en önemli fonksiyonunun yasa önünde eşitliği sağlamak olduğu söylenebilir. Bunun dışında Halk Meclisinin özgürlerin kabile mensubiyetlerini dengeli bir şekilde gözeterek alt düzeyde memurluklara atamasında söz sahibi olduğu görülür.

Beşyüzler Meclisi, iktidarı elinde tutan erk için kabileler veya bölgeler ile oranlı olarak ve yine iktidar sahipleri tarafından kura ile belirlenmekteydi. Öncesinde Politai (özgürler) arasında belli bir sınıfa has olarak meydana gelen ve iktidar erkinin danışma heyeti konumunda olan bu meclis, demokratik reformlardan sonra Politai arasında daha dengeli bir dağılıma kavuşturulmuştur. Dolayısıyla Beşyüzler Meclisinin doğrudan yürütmeyi üstlenen bir meclis olarak değil iktidar erki ya da yürütme için bir danışma konseyi niteliğinde olduğu söylenebilir.

Demokrasinin önemli ölçütlerinden biri olarak görülen 'kanun önünde eşitlik' (Özbudun, 2015, s. 75) kadınlar, köleler ve yabancılar hariç tutulacak olursa Kadim Yunan'da ulaşılan en önemli başarı olarak görülebilir. Esasında Halk Meclisi gibi demokratik kurumların ilk ortaya çıkış gerekçesi de bu konudaki suiistimalleri önlemek olmuştur.

\section{Antik İsrail Devletinin Kralları: Davud ve Süleyman Peygamberler Dönemi}

Bu başlıkta Antik Yunan'dan önce Kadim İsrail Devletinde yaşanan iptidai demokratik tecrübelerin izleri aranacaktır. Tevrat'ta Kur'an'da ve peygamberler tarihi ile ilgili yazılan kitaplarda belirtildiği gibi Hz. Yakup'un (İsrail) çocukları olan İsrailoğulları Mısır'daki Firavun idaresinin altında bir nevi esaret hayatı yaşamaktaydı. Hz. Musa İsrailoğullarına gönderilmiş bir peygamber olarak kendi kavmini Firavun'un zulmünden ve esaretinden kurtarma misyonunu da yüklenmişti. Dolayısıyla Musa peygamber İsrailoğullarını Firavun'un hükmünden kurtarıp onları atalarının toprakları olan Kenan'a (bugünkü Filistin) getirmek için çabalıyordu. Hz. Musa İsrailoğullarını Firavun'dan kurtarıp Tih Sahrasına kadar getirdi. İsrailoğulları sözü edilen sahrada iken Hz. Musa, kendisine vahiy yoluyla gelen kutsal kitap Tevrat'nn yazılı olduğu kitabeleri içeren mukaddes sandığı da onlara miras olarak bırakıp, vefat etti. Musa peygamberden sonra İsrailoğullarına $\mathrm{Hz}$. Yuşa Peygamber olarak görevlendirildi. İsrailoğullarını Tih sahrasından Yuşa Peygamber çıkardı (Ahmet Cevdet Paşa, 1966, s. 30-32). Tevrat'a göre İsrailoğullarının Hz. Yuşa (as)'dan Hz. İşmoil(as)'e kadar devam eden devresine 'Hakimler Dönemi' denilmektedir (Kızıloğlu, 2012, s. 39). Hakimler Dönemi İsrailoğullarının kendi içlerindeki idarelerinin yerel bir yönetici konumunda olan Hakimler tarafından yürütüldüğü devredir. İsrailoğullarının on iki kabilesi olan Esbat-1 Beni İsrail'in bütünü bu hakimlere itaat eder ve onları yönetici konumunda tutardı (Ahmet Cevdet Paşa, 1966, s. 33).

Hakimler döneminin ne zaman başladığ 1 ve ne kadar sürdüğg̈ konusunda birbirinden farklı tarihler verilmektedir. Ahmet Cevdet Paşa (V. 1890) Hz. Musa'nın vefatından Hz. Davut'un $^{6}$ vefatına kadar geçen sürenin 535 sene olduğunu ifade etmektedir (1966, s. 33). Yine Ahmet Cevdet Pașanın verdiği tarihler miladi takvime uyarlandığında Hz. Davud'un vefatının MÖ 1181 tarihine denk geldiği görülmektedir. Hakimler döneminin MÖ 1200’lü y1llarda

\footnotetext{
${ }^{6}$ Hakimler döneminden sonraki Antik İsrail Devletinin ikinci kralı
} 
başladığı şeklinde kayıtlar da yer almaktadır (Kızıloğlu, 2012, s. 38). ${ }^{7}$ Tarihlendirme konusunda yaşanan bu farklılığın Tevrat nüshaları arasındaki uyumsuzluktan kaynaklandığı düşünülmektedir. ${ }^{8}$

İsrailoğulları son hükkam Hz. İşmoil'den', kendi toprakları olan Kenan'1 işgal eden Amalikalılara (Kurt, 2010, s. 552) karşı savaşmak üzere kendilerine bir melik nasb olunmasını istediler (Ebu Cafer Muhammed Bin Cerir'üt- Taberi, s. 490). Hz. İşmoil kendisine gelen vahiy gereği Talut' ${ }^{10}{ }^{10}$ melik olarak tayin eder (Yavaşoğlu, 2012, s. 43). Bu tayin aynı zamanda İsrailoğullarının hakimlik döneminden meliklik dönemine geçişini ifade etmektedir. Melikler ile hükkamlar arasındaki temel fark hükkamların daha çok bir aşiret beyi veya kanaat önderi konumunda olması idi (Arçın, 2016, s. 34). Bu dönemde başka aşiretlerle sözgelimi Filistilerle (bu günkü Filistin'e ismini veren ve şu anda tamamen asimile olan bir halk) hükkamlar önderliğinde çatışmalar yaşanıyor idiyse de bunlar kabile çatışmaları konumundaydı. Hükkamlar döneminde İsrailoğulları Amalikalıların yönetimi altında bulunan Kenan'da yaşamaktaydılar. Melikler döneminde İsrailoğulları bağımsız bir devlet olarak başka devletler ile savaşma ve bir toprak parçası (Kenan) üzerinde bağımsız olarak hükmetme sürecine girmişlerdir.

Talut Amalikalıların hükümdarı (Köksal, 2014, s. 508) veya güçlü bir savaşçısı (Tevrat, 1. Samul, 17:4) olan Calut ile yaptı̆̆ 1 savaşta galip geldi. Böylece İsrailoğulları, Tevrat'ın kendilerine vaad ettiğini iddia ettikleri Kenan ülkesinde Amelikalılara karşı bağımsızlıklarını elde etmiş oldular. Kazanılan savaşta Beniisrailin Yehuda oğulları koluna mensup olan Davut adında çobanlık yapan bir gencin sapan taşıla, Amalikalı kumandan Calut ${ }^{11}$ öldürüldü. Amalikalı kumandan Calut'u öldüren bu genç daha sonra Talut'un yerine İsrail oğullarının başına kral olacak olan Davut peygamberdi. İsrailoğulları ilk melik Talut liderliğinde kazandıkları bu savaş ile Amalikalılara karşı bağımsızlıklarını kazanmışlardı. Artık Kenan denilen ülkede bağımsız bir İsrailoğulları devleti kurulmuş olmaktaydı. Bu devletin kurucu iradesi Tevrat'taki ismi Saul olarak geçen Talut'tu. Tevrat'ta anlatılan bilgilere bakıldığında kurulan yeni devletin bazı özellikleri ile ilgili fikir sahibi olunabilmektedir. Yeni devlette erkeklerden meydana gelen, komuta kademesine bağl1 ve çeşitli büyüklüklerde hiyerarşik olarak sıralanmış bir ordu (Tevrat, 1. Samuel, 8: 11-12); yemek işleriyle ilgilenecek ve kadınlardan meydana gelecek bir harem olacaktır (Tevrat, 1. Samuel, 8: 13). Yönetim işinde bürokratlar ve memurların görev alacağı bir yapılanma (Tevrat, 1. Samuel, 8: 14-18); ve bu memurların ücretleri/maaşları ve diğer giderler için toplanacak aşar vergisinin toplanması de yeni devletin özellikleri arasında yer alacaktır (Tevrat, 1. Samuel, 8: 14-18). Musa Peygamberin şeriatına göre şekillenen ve hukuksal sorunların çözümünde hükkamlar döneminden beri uygulana gelen Ahid Kanunnamesi ise devletin hukuksal temelini oluşturacaktı. Ahid Kanunnamesi İsrail oğulları arasında sürekli uygulanagelmiş olan hukuk metinleri olarak örf haline gelmiş hukuk kurallarıydı. İsrail kralından beklenen bu yasal kurallar mecmuasına uygun davranmasiydı. Kitab-1 Mukaddes uzmanlarından olan George E. Mendenhall yeni kurulan İsrail devletinin,

\footnotetext{
${ }^{7}$ Hakimler dönemi ve diğer tarihi kayıtlarla ilgili birbiriyle uyumsuz bilgilerin kaynağı çelişkili bilgiler içeren Kitab-1 Mukaddes (Tevrat ve İncil) nüshalarıdır. İnsanlık tarihini anlatan Tevrat'tan başka bir kitap olmadığı ve Tevrat'ın nüshaları da birbiri ile uyumlu olmadığı için Kitab-ı Mukaddes referanslı yazılan eserlerde birbiriyle uyumsuz bilgilere rastlanmaktadır (Ahmet Cevdet Paşa, 1966, s. 32).

${ }^{8}$ Davut ve Süleyman peygamberlerin ne zaman yaşadıklarına dair verilerde bazı ihtilaflar olsa da bu makalenin konusu açısından yeterli olabilecek bilgiler bulunmaktadır. Buna göre Ahmet Cevdet Paşanın Kısas-1 Enbiya ve Tevarih-i Hulefa adlı kitabında verdiği bilgilerden anlaşıldığına göre Hz. Davud'un vefatı MÖ 1181'de olmuştur. Hz. Davud vefat ettiğinde hemen Süleyman Peygamber kral olmuş ve kırk yıl hükümdarlık yapmıştır. Dolayısıyla Hz. Süleyman MÖ 1141 civarı tarihlerde vefat etmiştir. Başka bir kaynakta Süleyman (as)'ın MÖ 928 veya 931 yıllarında vefat ettiği ifade edilmiştir (Harman, 2010, s. 60). Fakat Kitab-1 Mukaddes uzmanlarından George E. Mendenhall Hz. Süleyman'ın vefatı için MÖ 922 tarihini vermektedir (2016, s. 171). Yaklaşık 220 yıllık farkın nereden kaynaklandığı tam olarak bilinmemektedir.

9 Kitab-1 Mukaddeste İşmoil Peygamberin ismi Samuel olarak geçmektedir (Kutsal Kitap, 284). Bazı İslami kaynaklarda ise Şemuyel (as) olarak geçmektedir (Köksal, 2014, s. 499).

${ }^{10}$ Tevratta Talut'un ismi Saul olarak geçmektedir Tevrat, 1. Samuel, 10: 1).

${ }^{11}$ Kitab-1 Mukaddes'te Calut'un ismi Golyat olarak geçmektedir (Tevrat, 1. Samuel, 17: 51).
} 
kralın böyle yasal bir sınırlandırmaya tabi olmasından hareketle, anayasal monarşinin ilk örneği olarak kabul edilebileceğini ifade eder (2016, s. 143).

İşmoil peygamber İsrailoğullarının başlarına bir kral tayin edilmesine dair taleplerine ilkin, bu talebin bir devlet olmayı ve onun ise savaş ve vergi gibi mükellefiyetleri içerdiğinden hareketle, İsrailoğullarının bunları kabullenmeyecekleri düşüncesiyle bu talebe olumsuz cevap vermek istemişti. Fakat İsrailoğulları bu konuda ısrarcı olduklarında onlardan tekrar tekrar yeni duruma uyacakları konusunda teminatlar alarak yeni süreci başlatmıştır.

İlk İsrail kralı olarak belirlenen Talut'un vefatından sonra yerine kimim geçeceği konusunda İsrail oğulları arasında tartışma çıktı. Calut'u öldürmesiyle Hz. Davud'un İsrailoğulları arasındaki prestiji oldukça yükselmişti. İsrailoğullarının bu süreçte başlarına geçecek melik konusunda izledikleri yolun bu günkü seçim sistemine benzeyen biat yöntemi (Kallek, 1992, s. 120) olduğu söylenebilir. Talut'un ölümünden sonra yerine oğlu melik oluyor. Fakat İsrail oğulları arasına ayrılık giriyor. İsrailoğullarının on iki kabilesinden on biri Talut'un oğlunun melikliğini kabul ederken Yahuda oğulları kabilesi Hz. Davud'a tabi oluyor. Buna rağmen tartışmalar bitmiyor ve nihayetinde İsrailoğullarının bütün kabileleri Hz. Davud'a biat ediyorlar (Ahmet Cevdet Paşa, 1966, s. 34). Davud peygamberin İsrailoğulları devletinin ikinci meliki konumunda iktidara gelmesi, kendi kabilesi dışındaki kabileleri zor ve şiddet kullanarak kendi hükümranlığına boyun eğdirmesi şeklinde değil, İsrailoğullarının on iki kabilesinin de kendisine biat etmesiyle oluyor (Peygamberler Tarihi Ansiklopedisi IV. Cilt, 1990, s. 101). Tevrat'ta da bu yaklaşımı destekleyici bir anlatım üslubunun olduğu net olarak görülmektedir.

\footnotetext{
"2.Samuel 5: 1 İsrail'in bütün oymakları Hevron'da bulunan Davut'a gelip şöyle dediler: "Biz senin etin, kemiğiniz.

2.Samuel 5: 2 Geçmişte Saul kralımızken, savaşta İsrail'e komuta eden sendin. RAB sana, 'Halkım İsrail'i sen güdecek, onlara sen önder olacaksın diye söz verdi."

2.Samuel 5: 3 İsrail'in bütün ileri gelenleri Hevron'a, Kral Davut'un yanına gelince, kral, RAB'bin önünde orada onlarla bir antlaşma yaptı. Onlar da Davut'u İsrail Kralı olarak mesh ettiler (Tevrat, 2. Samuel 5: 1-3).”
}

Tevrat'ın bu ifadeleri Davud peygamberin İsrailoğullarının istemesiyle onların krallığını kabul ettiğini göstermektedir. Üstelik bu konuda tam bir ittifakın sağlandığ 1 da ifadelerden anlaşılmaktadır. Dolayısıyla Davud peygambere İsrailoğulları tarafından seçilmiş bir melik olarak bakılabilir. Burada Hz. Süleyman'ın İsrailoğullarının üçüncü meliki olmasından da bahsedilecek ve daha sonra genel bir değerlendirme yapılacaktır.

Davut Peygamber yaklaşık kırk yıl hükümdarlık yaptıktan sonra vefat etmiş ve yerine oğlu Hz. Süleyman melik olmuştur. Hz. Davud ve Hz. Süleyman'ın (as) İsrailoğullarının başına hükümdar olmaları Tevrat'ta bazı ayrıntılarla beraber şu şekilde ifade edilmektedir:

\footnotetext{
"Ve Davud İsrail'in bütün reislerini sıbtların reislerini ve krala nöbetle hizmet eden bölüklerin başbuğlarını ve binlerin başlarını ve yüzlerin başlarını ve kralla oğullarının bütün mallarının ve sürülerinin reislerini, kızlar ağalarını ve yiğitleri, bütün cesur yiğitleri Yeruşelim (Kudüs)'e topladı. Ve kral Davud ayağa kalktı ve dedi: "Ey kardeşlerim ve kavmim beni dinleyin... bütün oğullarımdan Rabbin İsrail üzerinde krallık tahtına oturmak için oğlum Süleyman'1 seçti... Ve bütün cemaat atalarının Allah'ı Rabbi takdis ettiler ve başlarını eğdiler (Kitab-1 Mukaddes, 1. Tarihler, Bab: 28)...”

“Ve Davud'un oğlu Süleyman'ı ikinci kere kral ettiler. Ve Rabb için reis olarak onu ve kahin olarak Tsodok'u meshettiler. Ve Süleyman babası Davud'un yerine kral olarak Rabbin tahtı üzerine oturdu. Ve işi iyi gitti ve bütün İsrail onun sözünü dinlediler. Ve bütün reisler ve yiğitler ve Kral Davud'un bütün oğulları da Kral Süleyman'a tabi oldular (Kitab-1 Mukaddes, 1. Tarihler, Bab: 29).”
}

Tevrat'ın bu ifadelerinden anlaşıldığı kadarıyla Davut Peygamber İsrailoğullarının bütün kabile büyüklerini, yönetici bürokrasiyi, ordu komutanlarını, hazine yöneticilerini, haremde bulunan yöneticileri ve diğer bazı önde gelenleri toplayarak oğlu Süleyman'1 kendi yerine kral olarak kabul etmelerin istedi. İsrailoğullarının önde gelen isimleri Hz. Süleyman'ı kral olarak kabul ettiler. Hz. Süleyman'ın diğer kardeşleri de onu kral olarak tanıdılar. Tevrat'ta geçen 'Ve bütün İsrail onun sözünü dinlediler' ifadesi Hz. Süleyman'ın krallığında İsrailoğullarının bir 
konsensüs sağladığını ve ittifakla onu krallık görevine seçtiklerini ifade etmektedir. Diğer bir ifade ile İsrailoğulları Hz. Süleyman'ın krallığını baskı ve zorlama olmadan kabul etmişlerdir.

Bazı İslami kaynaklarda ifade edildiğine göre Davud (as) Hz. Süleyman 12 yaşında iken onu beni İsrail alimlerinin huzurunda imtihan etti. Hz. Süleyman'in hem kendisinin hem de Beni İsrail alimlerinin sorduğu suallere vukufiyetle cevap verdiğini görünce onu kendi yerine Beni İsrail'in üzerine halife tayin etti. Fakat bu tayinin kabul ve geçerli olabilmesi için kendisi önde ve Süleyman (as) arkada olarak 'İşte bu, benden sonra sizin üzerinize halifemdir' diye İsrailoğulları arasında dolaştı. Hepsi Süleyman (as)'ın hilafetini kabul ettiler (Peygamberler Tarihi Ansiklopedisi IV. Cilt, 1990, s. 101). Buna göre önceden yapılan kamuoyu araştırmaları sonucu bir iktidar adayı belirleniyor ve bu aday o dönem için bir oylama yöntemi olarak kabul edilebilecek olan 'iktidar adayının halk arasında gezmesi ve halkın doğrudan demokrasi yoluyla gezen adaya oy vermesi' şeklindeki bir yöntemle iktidara getirilmiş oluyor. Bu olaydaki anlatım şekli ile Tevrat'ta bahsedilen İsrailoğullarının Hz. Davud tarafından toplanması arasında büyük bir benzerlik bulunmaktadır. Yukarıda ayrıntılı olarak geçtiği gibi eğer Hz. Davud Hz. Süleyman'1 zor kullanarak kendi yerine halife biraksayd1 o halde Hz. Süleyman'1 İsrailoğullarının huzurunda ilme göre imtihan etmesi ve Hz. Süleyman'ın hilafeti konusunu tartışmaya açması anlamsız olurdu.

Hz. Süleyman'ın İsrailoğulları tarafından kral olarak tanınmasının zor içermeyen hür irade ile olduğu, Davut Peygamberin kral seçilmesi sürecinde yaşanan tartışmalardan da anlaşılmaktadır. Yukarıda bahsedildiği gibi Birinci Melik Talut’tan sonra İsrail oğulları üzerine kral olarak Talut'un oğlu geçmiş ve Beniisrailin on iki kabilesinden on biri ona biat etmişti. Diğer kabile ise Hz. Davud'a biat etmişti. Fakat daha sonra Davut Peygamber herhangi bir güç kullanmadan diğer İsrailoğulları kabileleri Hz. Davud'a biat etmişlerdir (Mendenhall, 2016, s. 147).

Hz. Davud'un Hz. Süleyman'1 kendisi daha hayatta iken yerine kral olarak tayin etmesi ve İsrailoğullarının onun krallığını tanımasına; kendisinin kral olması sürecindeki gibi rızaya dayanan bir tercih olarak bakılabilir. Tevrat'ın ifadelerinde de buna dair ipuçları yer almaktadır. Tevrat'taki 'Ve Davud'un oğlu Süleyman'1 ikinci kere kral ettiler' ifadesi Hz. Süleyman'ın Hz. Davud'un vefatından sonra İsrailoğulları tarafından bir kez daha kral olarak tayin edildiğini göstermektedir. Tevrat'ın bu ifadesinden dolayı Hz. Davud'un son iki yılında Hz. Süleyman'ın da saltanata geçtiği ileri sürülmüştür (Arçın, 2016, s. 44). İfadelerden anlaşılan Hz. Davud'un son iki y1lında, Hz. Süleyman'ın saltanata geçtiği ve Hz. Davud'un kendi tercihiyle daha pasif bir konumu seçtiğidir. Eğer Hz. Davut saltanatının gücünü kullanarak Hz. Süleyman'ı kendi yerine halife bıraksaydı Hz. Davud'un vefatından sonra İsrailoğullarının Hz. Süleyman'1 ikinci kez kral seçmemeleri gerekirdi. Dolayısıyla söylenebilir ki Hz. Davut (as) ve Hz. Süleyman (as) bugünkü literatür olarak seçimle ifade edilen zor içermeyen 'biat' yöntemiyle krallığa seçilmişlerdir. Biatin Tevrat'taki karşılığının 'mesh etme' kavramı olduğu görülmektedir (Mendenhall, 2016, s. 157; Kitab-1 Mukaddes, I. Tarihler, 11. ve 19. Baplar).

Süleyman peygamberin meşru biat yöntemi ile krallığa geldiğini gösteren diğer bir delil İsrail devletinin onun vefatından sonra, Yahuda ve İsrail Devletleri olarak ikiye bölünmesidir (Ahmet Cevdet Paşa, 1966, s. 34). Hz. Süleyman'ın vefatından sonra İsrail oğullarının on kabilesi İsrail Devletini, Hz. Süleyman'ın kabilesi ve Bünyaminoğulları ise Yahuda Devletini meydana getiriyorlar. Başka bir ifadeyle Süleyman peygamberin vefatından sonra İsrailoğullarının büyük bir kısmı Süleyman (as)'ın kabilesinin aleyhine geçiyorlar. İsrailoğullarının Davut ve Süleyman (as)'a biatları zorla olsaydı söz konusu biatın hanedan ailesince bu peygamberlerin vefatından sonra da sürdürülmesi beklenirdi. Demek söz konusu biat zorla değil gönüllü olarak gerçekleşmiştir denilebilir. Davut peygamberin İsrailoğulları üzerine ikinci melik/kral olarak seçilmesinin peygamberliğinden önce gerçekleşmiş olması da İsrailoğullarının biatinin gönüllü olduğu yaklaşımını desteklemektedir (Peygamberler Tarihi Ansiklopedisi IV. Cilt, 1990, s. 79). Diğer bir ifadeyle $\mathrm{Hz}$ Davud'un krallı̆̆ına razı olduklarından dolayı ona biat eden İsrailoğulları, Hz. Davud'u peygamber olarak kabul edip 
krallığına tabi olmayı peygamberliğine tabi olmanın gereği olarak görüp tabi olmamışlardır. Hz. Davud'a Peygamberlik, kendisi kral seçildikten sonra verilmiştir.

İsrail oğullarının ilk devletleşme sürecinde iki peygamber önderliğinde yaşanan tecrübeler göstermektedir ki devlet yöneticisinin toplumsal rızaya dayalı olarak belirlenmesinin doğu toplumlarında oldukça eskiye dayanan bir geçmişi bulunmaktadır. Mendenhall'ın Davud Peygamberin yönetim şeklini anayasal monarşinin ilk örneği olarak nitelendirdiğinden daha önce bahsedilmişti. Daha ileri bir değerlendirme olarak ilk İsrail Devletinin ikinci ve üçüncü kralları olan Hz. Davud ve Hz. Süleyman (as) dönemlerindeki idare sistemine cumhuriyet yönetiminin ilk örnekleri olarak bakılabilir. Tevrat'ta anlatılan bilgilerin -Tevrat'in İslam inancına göre muharref olduğu düşüncesinden dolay1- delil teşkil etmeyeceği ileri sürülebilir. Tevrat'ın muharref olması içindeki hiçbir bilginin gerçeklik taşımadığı anlamına gelmemelidir. Diğer taraftan bu makalede Tevrat'tan yapılan aktarmalar tek başına delil olarak gösterilmemekte İslami kaynaklardan da konuyu destekleyici verilere yer verilmektedir.

Antik İsrail devletinde Talut'un ve Davut ve Süleyman peygamberlerin iktidara geliş yöntemlerinin Beniisrail'in 12 kabilesinin onayı ile olmasından hareketle toplumsal rizaya dayandığı görülmektedir. İktidarın bu şekilde elde edilmesinin demokrasinin en önemli mihenklerinden biri olan 'kim yönetecek?' sorusuna demokratik bir cevap içerdiği söylenebilir. Seçilen kralın Ahid Kanunnamesine uymak zorunda olması yetkilerinin mutlak olmadığını göstermektedir. Siyasal iktidarın meşruluk kaynağının Kadim İsrail'de toplumsal rıza olması Antik Yunan'da bulunmamaktaydı. Kadim İsrail'de iktidar erki anayasa ile sınırlandırılmış olmasına rağmen halk tarafından seçilen doğrudan veya dolaylı bir kurum (meclis) ile sınırlandırılmamış olması ise Kadim İsrail'de bulunmamaktaydı. Dolayısıyla Antik İsrail'de siyasal iktidar sahibinin yürütme ve yarg1 yetkilerini birlikte kullandığ görülmektedir. Ayrıca yapılan bu değerlendirmelerin ilgili dönemin siyasal işleyişinin ayrıntılarının yeterince çalışılmamış olmasından kaynaklanan bilgi eksikliklerinden kaynaklanmış olabileceği de göz önünde bulundurulmalıdır.

\section{Sebe Kraliçesi Belkıs'ın Yönetimi}

Tevrat'ta Sebe melikesi hakkında sadece melikenin Saba denilen ülkenin kraliçesi olduğu, İsrail kralı Süleyman Peygamberin saltanatının ihtişamını duyup hayran kaldığı, bundan dolayı onu ziyaret ettiği anlatılmaktadır. Saba kraliçesi Süleyman Peygamberin saltanatını görünce hayretler içerisinde kalmıştır. Bu ziyarette kraliçe Hz. Süleyman'a çeşitli hediyeler getirmiş ve ona çeşitli sorular sormuştur. Hz. Süleyman Saba kraliçesinin bütün sorularına cevap vermiştir. Saba Melikesi ile ilgili kıssa Tevrat'ta iki kere ve hemen hemen aynı ifadelerle tekrar edilmektedir. Tevrat'ın Saba kraliçesi ile ilgili verdiği bilgi bu kadardır (Tevrat, I. Krallar, Bab: 10; Tevrat, II. Tarihler, Bab: 9).

Tevrat'ın verdiği bilgilerden hareketle Sebe melikesinin yönetimi konusunda bilgi sahibi olmak mümkün görünmemektedir. Dolayısıyla bir Kur'an kıssası olarak Sebe melikesinin yönetiminin sahip olduğu özellikler konusunda İslami kaynaklardan yararlanmak zorunluluğu vardır. Sebe Melikesi ile ilgili kıssa Kur'an'da yer aldığı için konu ile ilgili hem tefsir kitaplarında hem de hadis kitaplarında açıklayıcı bilgilere yer verilmektedir. Fakat Sebe melikesi ile ilgili tefsir kitaplarında verilen bilgiler konusunda eleştirel yaklaşımlar da bulunmaktadır (Duman, 2013, s. 319-325). Bu makalede bir Kur'an kıssası olan Sebe Melikesi ile ilgili, doğrudan Kur'an ayetlerinden verilen referanslara bağlı kalınarak değerlendirmeler yapılacaktır.

Sebe melikesinin ismi Tevrat'ta ve Kur'an'da geçmemektedir (Duman, 2013, s. 321). Fakat Kur'an tefsirlerinin çoğunda ve neredeyse bütün İslami kaynaklarda melikenin isminin Belkıs olduğu ifade edilmektedir. ${ }^{12}$ Sebe Melikesi ile ilgili kıssa Kur'an'da Neml suresinde

${ }^{12}$ https://kuran.diyanet.gov.tr/tefsir/Neml-suresi/3176/17-30ayet-tefsiri, Er Tr: 9.4.2019 
anlatılmaktadır (Kur'an, 27/22-44). Bu kıssada Hz. Süleyman'ın, Sebe ülkesinde güneşe tapan ve kendilerine bir kadının hükümdarlık yaptığı bir kavme dair bir bilgi aldığı belirtilir. $\mathrm{Bu}$ bilgiye binaen Süleyman peygamber Sebe melikesine mektup yazar ve bu mektupta onu ülkesiyle beraber kendisine tabi olmaya çağırır. Sebe Melikesine Süleyman peygamberin mektubu ulaşınca Melike ülkesinin ileri gelenlerini toplar ve mektup konusunda müzakere yapıldıktan sonra çizilen yol haritasına göre hareket edilerek nihayetinde melike $\mathrm{Hz}$. Süleyman'a hem tabi olur hem de iman eder. Kıssanın bu makale açısından değerlendirilecek tarafları melikenin idaresinin karakteristik özelliklerinin çözümlenmesine yönelik olarak verilen ifadeler olacaktır.

Hz. Süleyman'ın mektubu Melike Belkıs'a ulaşınca Melike'nin tepkisi Kur'an'da şu şekilde ifade edilmektedir: "Ey ileri gelenler (bu) işim hakkında bana fetva verin. (Ben, sizler yanımda) şahid olmadıkça (size danışmadan) hiçbir iş (hakkında karar)'ımı kat'ileştirici değilim" (Hayrat Neşriyat Kur'an meali, 27/32). Bu ayette konunun ifade ediş tarzından anlaşıldığı gibi Melike Belkıs başka bir ülkenin en üst yöneticisinden gelen bir mektup üzerine konuyu 'ileri gelenler meclisi'nde tartışmaya açmıştır. Ayetin ifadelerinden anlaşıldığ 1 gibi 'ileri gelenler meclisi'nde yönetimin icraatları veya ülkenin sorunlarıla ilgili konuların tartışılmasının rutin bir uygulama olduğu '(Ben, sizler yanımda) şahid olmadıkça (size danışmadan) hiçbir iş (hakkında karar)ımı kat'ileştirici değilim' ifadelerinden anlaşılmaktadır. Melike Belkıs'ın ülke yönetimi ile ilgili bütün kararlarına son şekli bu mecliste çıkan karara göre verdiği ifade edilmektedir. Kur'an'da yer alan bu ifadeler ile ilgili tefsir kitaplarında ayrıntılı bilgiler yer almaktadır.

Belkıs yönetiminin ülke meselelerini mecliste tartışarak sonuca bağladığı Kur'an ayetinin ifade tarzından da anlaşılmaktadır (Kur'an, 27/32). Son dönem müfessirlerinden Muhammed Hamdi Yazır Belkıs yönetiminin Meşruti idareyi andıracak şekilde olduğunu belirtmektedir:

\begin{abstract}
“'Hatta taşhadun' (siz olmadığınız sürece) $)^{13}$ denilmesinden bunların mühim işleri müşavere için huzurunda toplanması mu'tad olan bir heyet olduğu anlaşılıyor. Bunların her biri on bin kişiyi temsil etmek üzere 312 kişi olduğu da rivayet edilmiştir. (Katade). Bu heyete iyrad olunan bu noktada şimdiye kadar emr-i hükümette istibdat yapılmamış olması medh ve reiy(rey)lerinin esas tutulmus olduğu beyan olunmak suretiyle cemile gösterilerek meşveretin ehemmiyeti tesbit edilmiştir ki bunun zahiri (belirgin) bir meşrutiyet teamülü anlatmaktadır." (Yazır, 1938, s. 3676).
\end{abstract}

Belkıs'ın idaresinde bir meşveret meclisinin bulunduğu ilk dönem müfessirlerin tefsirlerinde de yer almaktadır (İbn-i Kesir, XI. Cilt, 1993, s. 6141). Sadece meşveret meclisinde kaç kişinin olduğu konusunda farklı sayılar verilmektedir. Sebe Melikesi Belkıs'ın yönetiminin meşruti bir idareyi andırdığı ayetin ifadeleriyle netleşmektedir. Bir devlet başkanı olan Belkıs'ın kendi meşveret meclisine hitap ediş şeklinden meclisin yetkileri konusunda bir fikir edinmek mümkün olmaktadır. Belkıs meclise 'size danışmadan hiçbir işimi kesinleştirici değilim' demektedir. Bu ifadelerde yer alan 'danışma' kavramı konuların bu mecliste müzakere edildiğini göstermektedir. 'Hiçbir işimi kesinleştirici değilim' sözü ise meclisin devlet yönetimi ile ilgili konulara melike ile birlikte son şeklini verdiği bir karar mercii olduğu anlaşılmaktadır. Büyük müfessir Fahruddin er-Razi ayetin Arapçasında geçen 'aftuni' (bir fetva verin) ifadesi için kelimenin fetva kavramından geldiğini, onun kökünün ise feta (genç) kavramına dayandığını, dolayısıyla bu kavramın 'yeni meydana gelen bir hadise için belirtilen görüş' olduğunu ifade etmektedir (17. Cilt, 1990, s. 423). Yeni meydana gelen bir olay veya konunun mecliste görüşülüp karar altına alındığını göstermektedir. Dolayısıyla bu heyet bir yasama meclisi konumundadır. Yeni gündemler karar altına alınmakta ve uygulaması yürütme konumunda olan melikeye bırakılmaktadır. Kur'an ayetlerinin Belkıs yönetimi ile ilgili verdiği bu bilgilerden özet olarak çıkarılabilecek sonuçlar için şunlar söylenebilir: 1- Belkıs yönetimi mutlakiyetçi değil meşruti bir yönetimdir. 2- Yasama ve yürütme iç içe bulunmaktadır. Kraliçe

\footnotetext{
${ }^{13}$ http://kuranmeali...sure=27\&ayet=32...elmalili, Er Tr: 10.4.2019
} 
ve kraliçenin kararlarına son şeklini verdiği bir yasama meclisi bulunmakta, meclisten çıkan kararların yürütmesi melikeye bırakılmaktadır. $\mathrm{Bu}$ özelliklerinden dolayı Belkıs idaresine parlamenter Demokrasinin ilk örneği olarak bakılabilir. ${ }^{14}$ İlgili döneme ait kaynaklar ya yetersiz olduğu ya da yeterince incelenmediği için bu dönemde yarg1 erkinin mahiyeti ile ilgili yeterince bilgi bulunmamaktadır. Yukarıda bahsedilen özelliklerinden anlaşılmaktadır ki Belkıs yönetimi Antik Yunan'dan oldukça ileri düzeyde bir demokratik içeriğe sahip olmuştur. Belkıs'ın siyasal iktidarı toplumsal rızayı ifade eden bir yöntemle mi yoksa soy bağına bağlı bir yöntemle mi elde ettiği konusunda şimdilik bir veri bulunmamaktadır. Konunun bu kısmı daha derin ve kapsamlı incelemeler ile ortaya çıkarılmalıdır.

\section{Sonuç ve Öneriler}

$\mathrm{Bu}$ makalede Davut ve Süleyman peygamberlerin Antik İsrail Devletinde ikinci ve üçüncü kral olma yöntemleri incelendi. Çalışmada ağırlıklı olarak Kitab-1 Mukaddes verilerinden hareket edildi. İslami kaynaklarda yer alan bilgilere ise tamamlayicı ve destekleyici veriler olarak yer verildi. Elde edilen verilere bakıldığında bu peygamberlerin iktidara gelme metodu ve uyguladıkları yönetim şeklinin Cumhuriyet yönetiminin ilk örnekleri olduğu söylenebilir.

Kitab-1 Mukaddes'te Saba Kraliçesi olarak geçen ve Kur'an'da ise Sebe melikesi olarak yer alan Belkıs yönetimi ile ilgili ise doğrudan İslami kaynaklardan hareket etme zorunluluğu bulunmaktadır. Çünkü Tevrat'ta sözü edilen kraliçenin yönetim metodu ile ilgili referans olabilecek bir içerik bulunmamaktadır. Kur'an'da ise kısa olmakla beraber birçok referanslar içeren bilgiler yer almaktadır. Bu çalışmada Sebe Melikesi ile ilgili değerlendirmelerde en temel kaynak olarak Kur'an'ın değerlendirmelerine yer verildi. İkinci olarak da Melike Belkıs ile ilgili bazı İslami kaynaklarda yer alan ve Kur'an ifadeleri ile uyumlu olan bilgilere yer verildi.

Davud ve Süleyman peygamberlerin ne zaman yaşadıkları konusunda yukarıda yapılan kritiğe göre batılı kaynaklarda H. Süleyman'ın M. Ö. 922 yılında vefat ettiğine dair değerlendirmeler bulunmaktadır (Mendenhall, 2016, s. 171). İslami kaynaklarda ise $\mathrm{Hz}$. Süleyman'ın vefat tarihi için M. Ö. 1141, 928, 931 gibi birbirinden farklı tarihler verilmektedir (Ahmet Cevdet Paşa, 1966, s. 35-45; Harman, 2010, s. 60). Süleyman Peygamberin yaşadığ tarih döneminin bu çalışma açısından önemi Doğu toplumlarında demokratik idarelere örnek gösterilebilecek yönetimlerin tarihine işaret etmek içindir. Buna göre ortaya çıkan sonuç için denilebilir ki; M.Ö. X. yüzyıla kadar uzanan bir tarihte, özellikle antik medeniyetlerin merkezi olan orta doğu coğrafyasında demokratik uygulamalara örnek olabilecek birçok tarihsel tecrübe yaşanmıştır. Doğu/Asya toplumlarından olan Çin, Hint, İran, Rus ve Türk tarihleri de incelenerek konu hakkında daha kapsamlı çalışmaların yapılması gerekmektedir.

\footnotetext{
${ }^{14}$ Melikenin Süleyman Peygamberin mektubu ile ilgili konuyu meclis gündemine getirirken kullandığı 'emr' kavramı Türkçeye genellikle 'iş’ olarak çevrilmektedir (http://kuranmeali...=golpinarli..=32, -Er Tr: 10.4.2019). Melikenin konuyu bir 'emr' olarak meclisin gündemine taşıması Kur'an'ın aynı zamanda Melikenin yönetim şeklini/metodunu övdüğünü de göstermektedir. Çünkü Kur'an'ın iki ayetinde 'emr'lerin Şura ile olması gerektiğinden bahsedilmektedir. Emruhum şura beynahum (Kur'an, 42/38). Onlar(Rablerine inanan ve tevekkül edenler)ın aralarındaki 'emr'leri şura iledir. Veşavirhum fil emr ('emr'ini onlara danış) (Kur'an, 3/ 159). Peygambere hitaben gelen bu ayette Peygamberden 'emr'lerini ashabına danıșarak karara bağlaması söylenmektedir. Bu iki ayette 'emr' kavramı ile ifade edilen işlerin meşveret/istişare ile karara bağlanması istenmektedir. Dolayısıyla Kuran'ın Sebe melikesi Belkıs'ın ve kavminin güneşe tapmasını 'şeytan işi' olarak görürken((Hüdhüd)‘Onun ve kavminin, Allah'ı bırakıp güneşe secde ettiklerini gördüm. Şeytan, kendilerine yaptıklarını süslü göstermiş de onları doğru yoldan alıkoymuş. Bunun için hidayete giremiyorlar.' (Kur'an, 27/24) ) 'emr'lerini şura ile halletmeye çalışmalarını ise 'mümince bir özellik' olarak değerlendirdiği söylenebilir.
} 


\section{Kaynakça}

Ahmet Cevdet Paşa, (1966). Kısas-ı Enbiya ve Tevarih-i Hulefa, Cilt: 1, İstanbul: Bedir Yayınevi.

Arçın, Ş. A. (2016). İsrail ve Yahuda Krallıkları Tarihi, 1. Baskı, İstanbul: Ayışığı Yayınları.

Çınar, M. (2016). “Demokrasi”, Siyaset (Ed. Yüksel Taşkın), 2. Baskı, İstanbul: İletişim Yayınları.

Ebu Cafer Muhammed Bin Cerir'üt- Taberi, Tarih- Taberi(Ter: M. Faruk Gürtunca), 1. Cilt, İstanbul: Sağlam Yayınevi.

Fahruddin er-Razi, (1990). Tefsir-i Kebir, (Tercüme: Suat Yıldırım, Lütfullah Cebeci, Sadık Kılıç, Sadık Doğru), 17. Cilt, Akçağ Yayınları, Ankara.

Duman, C. (2013). Üç Kral İki Peygamber, 1. Baskı, İstanbul: Pınar Yayınları.

Harman, Ö. F. (2010) "Süleyman”, 38. Cilt, İstanbul: TDV İslam Ansiklopedisi.

Heyet (2012). Kur'an-ı Kerim ve Muhtasar Kelime Meali İstanbul: Hayrat Neşriyat.

https://kuran.diyanet.gov.tr/tefsir/Neml-suresi/3176/17-30-ayet-tefsiri, -Er Tr: 9.4.2019).

http://kuranmeali.com/Kelime.php?sure=27\&ayet=32\&meal=elmalili, - Er Tr: 10.4.2019).

http://kuranmeali.com/Kelime.php?meal=golpinarli\&sure=27\&ayet=32, -Er Tr: 10.4.2019.

https://www.academia.edu/4023971/Antik_Yunan_Demokrasisi__Modern_Demokrasi_Kar\%C 5\%9F\%C4\%B1la\%C5\%9Ft\%C4\%B1rmas\%C4\%B1_Comparison_of_Ancient_Greek_Dem ocracy_and_Modern_Democracy_, (Er. Tr: 5.5.2020).

https://www.academia.edu, (Er. Tr: 7.5.2020), Akgün, E. (2011). “Antik Yunan'da Yurttaşların Özgürlüklerinin Temeli Olarak Demokrasi”

İbn-i Kesir, (1993). Hadislerle Kur'an-ı Kerim Tefsiri, (Çev: Bekir Karlıăga, Bedrettin Çetiner), XI. Cilt, 1. Baskı, İstanbul: Çağrı Yayınları.

Kallek, C. (1992). "Biat”, 6. Cilt, İstanbul: TDV İslam Ansiklopedisi.

Kızıloğlu, S. (2012). "İsrail Devletinin Kuruluşuna Kadar Geçen Süreçte Yahudiler ve Siyonizm'in Gelişimi”, Kırıkkale Üniversitesi Sosyal Bilimler Enstitüsü Sosyal Bilimler Dergisi, 2(1): 35-64.

Köksal, M. A. (2014). Peygamberler Tarihi, 19. Bask1, İstanbul: Türkiye Diyanet Vakfı Yayınları.

Kurt, A. O. (2010). “Talut”, 39. Cilt, İstanbul: TDV İslam Ansiklopedisi.

(2014). Kutsal Kitap (Tevrat, İncil. Zebur), İstanbul: Yeni Yaşam Yayınlar1.

Mendenhall, G. E. (2016). Antik İsrail 'in İnancı ve Tarihi(Çev: Mia Pelin Özdoğru), 1. Bask1, İstanbul: İnsan Yayınları.

(1990). Peygamberler Tarihi Ansiklopedisi IV. Cilt(Heyet), İstanbul: İhlas Matbaacilık, Gazetecilik ve Sağlık Hizmetleri A. Ş., (Türkiye Gazetesi).

Özbudun, E. (2015). Anayasalcıllk ve Demokrasi, İstanbul: İstanbul Bilgi Üniversitesi Yayınları.

Şenel, A. (1995) Siyasal Düşünceler Tarihi, 4. Baskı, Ankara: Bilim ve Sanat Yayınları.

Tekin, O. (2008). Eski Yunan ve Roma Tarihine Giriş, İstanbul: İletişim Yayınları.

tr.wikipedia.org, Atina Demokrasisi maddesi (Er Tr: 8.5.2020). 
Yazır, M. H. (1938). Hak Dini Kur'an Dili(V. Cilt), 1. Bask1, Matbaa-i Ebüzziya, İstanbul. Yavaşoğlu, A. (2012). Saul ve Davut, 1. Bask1, Ankara: Kent Kitap.

\section{ETİK ve BİLIMSEL İLKELER SORUMLULUK BEYANI}

$\mathrm{Bu}$ çalışmanın tüm hazırlanma süreçlerinde etik kurallara ve bilimsel atıf gösterme ilkelerine riayet edildiğini yazar(lar) beyan eder. Aksi bir durumun tespiti halinde Afyon Kocatepe Üniversitesi Sosyal Bilimler Dergisi'nin hiçbir sorumluluğu olmayıp, tüm sorumluluk makale yazarlarına aittir. 